\title{
The molecular structure of matioliite $-\mathrm{NaMgAl}_{5}\left(\mathrm{PO}_{4}\right)_{4}(\mathrm{OH})_{6} \cdot 2\left(\mathrm{H}_{2} \mathrm{O}\right)-\mathrm{A}$ pegmatite mineral from Minas Gerais, Brazil
}

\author{
Ricardo Scholz ${ }^{\mathrm{a}}$, Yunfei Xi ${ }^{\mathrm{b}}$, Ray L. Frost ${ }^{\mathrm{b}, *}$ \\ ${ }^{a}$ Geology Department, School of Mines, Federal University of Ouro Preto, Campus Morro do Cruzeiro, Ouro Preto, MG 35400-00, Brazil

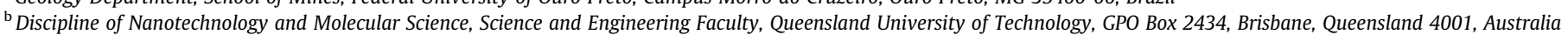

\section{H I G H L I G H T S}

- We have studied the pegmatite phosphate mineral matoiliite.

- The composition of the mineral was determined.

- The structure was assessed using vibrational spectroscopic techniques.

- Vibrational spectroscopy proves the existence of hydrogen phosphate and dihydrogen phosphate units in the structure of matioliite.

\section{A R T I C L E I N F O}

\section{Article history:}

Received 16 May 2012

Received in revised form 20 September 2012

Accepted 21 September 2012

Available online 22 October 2012

\section{Keywords:}

Matioliite

Phosphate

Pegmatite

Infrared spectroscopy

Scanning electron microscopy

Raman spectroscopy

\begin{abstract}
A B S T R A C T
Detailed spectroscopic and chemical investigation of matioliite, including infrared and Raman spectroscopy, scanning electron microscopy and electron probe microanalysis has been carried out on homogeneous samples from the Gentil pegmatite, Mendes Pimentel, Minas Gerais, Brazil. The chemical composition is (wt.\%): $\mathrm{FeO} 2.20, \mathrm{CaO} 0.05, \mathrm{Na}_{2} \mathrm{O} 1.28, \mathrm{MnO} 0.06, \mathrm{Al}_{2} \mathrm{O}_{3}$ 39.82, $\mathrm{P}_{2} \mathrm{O}_{5}$ 42.7, $\mathrm{MgO} 4.68, \mathrm{~F}$ 0.02 and $\mathrm{H}_{2} \mathrm{O} 9.19$; total 100.00 . The mineral crystallize in the monoclinic crystal system, $C 2 / c$ space group, with $a=25.075(1) \AA, b=5.0470(3) \AA, c=13.4370(7) \AA, \beta=110.97(3)^{\circ}, V=1587.9(4) \AA^{3}, Z=4$.

Raman spectroscopy coupled with infrared spectroscopy supports the concept of phosphate, hydrogen phosphate and dihydrogen phosphate units in the structure of matioliite. Infrared and Raman bands attributed to water and hydroxyl stretching modes are identified. Vibrational spectroscopy adds useful information to the molecular structure of matioliite.
\end{abstract}

(ㄷ) 2012 Elsevier B.V. All rights reserved.

\section{Introduction}

Matioliite is a rare hydrated basic aluminum phosphate mineral with sodium and magnesium, and shows general chemical formula expressed by $\mathrm{NaMgAl}_{5}\left(\mathrm{PO}_{4}\right)_{4}(\mathrm{OH})_{6} \cdot 2\left(\mathrm{H}_{2} \mathrm{O}\right)$. It was first described from the Gentil mine, a granitic pegmatite located at Mendes Pimentel, Minas Gerais, Southeastern Brazil. Matioliite forms a solid solution with burangaite - $(\mathrm{Na}, \mathrm{Ca})(\mathrm{Fe}, \mathrm{Mg}) \mathrm{Al}_{5}\left(\mathrm{PO}_{4}\right)_{4}(\mathrm{OH})_{6} \cdot 2\left(\mathrm{H}_{2} \mathrm{O}\right)$ [1], the $\mathrm{Fe}^{2+}$ end member of a $\mathrm{Mg}$-Fe series. In addition to burangaite, matioliite is isostructural with dufrénite and natrodufrénite, and crystallize in the monoclinic crystal system, $C 2 / c$ space group with $a=25.075(1) \AA, \quad b=5.0470(3) \AA, c=13.4370(7) \AA, \quad \beta=110.97(3)^{\circ}$,

\footnotetext{
* Corresponding author. Tel.: +61 73138 2407; fax: +61 731381804 .

E-mail addresses: r_scholz_br@yahoo.com (R. Scholz), r.frost@qut.edu.au (R.L. Frost).
}

$V=1587.9(4) \AA 33, Z=4$ [2]. After the type locality, other two occurrences are known in Eureka Co. in Nevada, USA [3] and Hochgosch in Carinthia, Austria [4].

Matioliite occurs as secondary phosphate mineral in lithium bearing pegmatites with primary montebrasite and triphylite and is associated with brazilianite, gormanite, fluorapatite and crandallite, forming a paragenesis in a phosphate rich hydrothermal system $[5,6]$.

According to Selway et al. [7], the fundamental building block of the structure of burangaite, as well as matioliite, is a face-sharing triplet of octahedra $[\mathrm{Al} \chi 6-\mathrm{Mg} \chi 6-\mathrm{Al} \chi 6]$ corner linked to two $\mathrm{Al} \chi 6$ octahedra and two $\mathrm{PO}_{4}$ tetrahedra, were $\chi$ is an unspecified anionic species. This block is polymerized parallel to the $c$-axis to form dense slabs in the $\{100\}$ plane. Alternating $\mathrm{Al} \chi 6$ octahedra and Na $\chi 8$ polyhedra form a chain parallel to the $c$-axis, and the dense slab and chain alternate along the $a$-axis. Al occurs at three symmetrically distinct sites coordinated in an octahedral arrangement. The Al1 site is coordinated by two $\mathrm{O}$ anions, two $(\mathrm{OH})$ groups and two $\left(\mathrm{H}_{2} \mathrm{O}\right)$ groups. The $\mathrm{Al} 3$ site is coordinated by three $\mathrm{O}$ 
anions and three $(\mathrm{OH})$ groups. The Al4 site is coordinated by four $\mathrm{O}$ anions and two $(\mathrm{OH})$ groups. Phosphorus occurs at two symmetrically distinct sites, each coordinated by four $\mathrm{O}$ in a tetrahedral arrangement. The Na site is coordinated by six $\mathrm{O}$ anions and two $\left(\mathrm{H}_{2} \mathrm{O}\right)$ groups to form a cubic antiprism. $\mathrm{Mg}$ atom is coordinated by four $\mathrm{O}$ anions and two $(\mathrm{OH})$ groups in an octahedral arrangement.

In recent years, the application of spectroscopic techniques to understand the structure of phosphates is increasing, with special attention to $\mathrm{Al}$ phosphates [8-12]. Farmer [13] divided the vibrational spectra of phosphates according to the presence, or absence of water and hydroxyl units in the minerals. In aqueous systems, Raman spectra of phosphate oxyanions show a symmetric stretching mode $\left(v_{1}\right)$ at $938 \mathrm{~cm}^{-1}$, the antisymmetric stretching mode $\left(v_{3}\right)$ at $1017 \mathrm{~cm}^{-1}$, the symmetric bending mode $\left(v_{2}\right)$ at $420 \mathrm{~cm}^{-1}$ and the $v_{4}$ mode at $567 \mathrm{~cm}^{-1}$ [14-16]. The value for the $v_{1}$ symmetric stretching vibration of $\mathrm{PO}_{4}$ units as determined by infrared spectroscopy was given as $930 \mathrm{~cm}^{-1}$ (augelite), $940 \mathrm{~cm}^{-1}$ (wavellite), $970 \mathrm{~cm}^{-1}$ (rockbridgeite), $995 \mathrm{~cm}^{-1}$ (dufrénite) and $965 \mathrm{~cm}^{-1}$ (beraunite). The position of the symmetric stretching vibration is mineral dependent and a function of the cation and crystal structure. The fact that the symmetric stretching mode is observed in the infrared spectrum affirms a reduction in symmetry of the $\mathrm{PO}_{4}$ units.

The value for the $v_{2}$ symmetric bending vibration of $\mathrm{PO}_{4}$ units as determined by infrared spectroscopy was given as $438 \mathrm{~cm}^{-1}$ (augelite), $452 \mathrm{~cm}^{-1}$ (wavellite), 440 and $415 \mathrm{~cm}^{-1}$ (rockbridgeite), 455,435 and $415 \mathrm{~cm}^{-1}$ (dufrénite) and 470 and $450 \mathrm{~cm}^{-1}$ (beraunite). The observation of multiple bending modes provides an indication of symmetry reduction of the $\mathrm{PO}_{4}$ units. This symmetry reduction is also observed through the $v_{3}$ antisymmetric stretching vibrations. Augelite shows infrared bands at 1205, 1155, 1079 and $1015 \mathrm{~cm}^{-1}$ [8]; wavellite at $1145,1102,1062$ and $1025 \mathrm{~cm}^{-1}$; rockbridgeite at 1145,1060 and $1030 \mathrm{~cm}^{-1}$; dufrénite at 1135,1070 and $1032 \mathrm{~cm}^{-1}$; and beraunite at 1150,1100, 1076 and $1035 \mathrm{~cm}^{-1}$.

In this work, spectroscopic investigation of a monomineral matioliite sample from the type locality in Brazil has been carried out. The analysis includes spectroscopic characterization of the structure with infrared and Raman spectroscopy.

\section{Methods}

\subsection{Sample preparation}

Light blue to greenish blue matioliite crystals were collected from the type locality, a granitic pegmatite named Gentil mine. The sample was incorporated in the collection of the Geology Department of the Federal University of Ouro Preto, Minas Gerais, Brazil, with sample code SAA-070. The crystals were hand selected

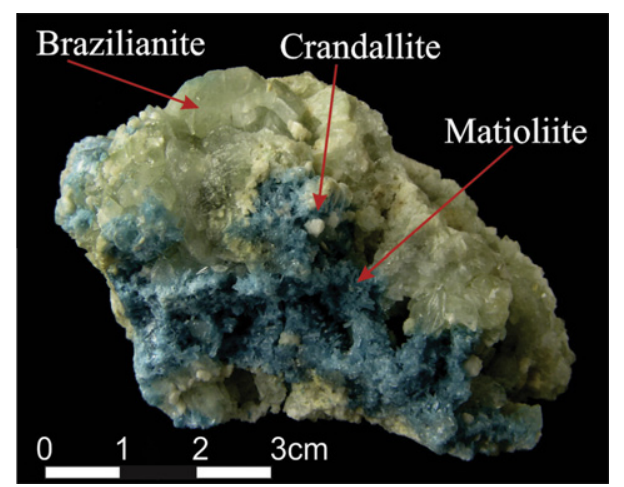

Fig. 1. Matioliite crystals in association with brazilianite and crandallite. from a sample in association with brazilianite and crandallite (Fig. 1).

The matioliite crystals were phase analyzed by X-ray diffraction and shows the following crystallographic parameters: $a=$ 25.012(3) Á, $b=5.0368(7) \AA, \quad c=13.4027(16) \AA \hat{A}, \quad \beta=110: 937(8)^{\circ}$, $V=1577.0(4) \AA^{3}, C 2 / c, Z=4$, showing similar of those published by Atencio et al. [2]. Two single crystals were prepared in polyester resin for quantitative chemical analysis, with five points analyzed in each crystal. The polishment was done in the sequence of $9 \mu \mathrm{m}, 6 \mu \mathrm{m}$ and $1 \mu \mathrm{m}$ diamond paste $\mathrm{MetaDI}^{\circledR}$ II Diamond Paste Buhler, using water as a lubricant, with a semi-automatic MiniMet $^{\circledR} 1000$ Grinder-Polisher-Buehler.

\subsection{Scanning electron microscopy (SEM)}

Matioliite samples were coated with a thin layer of evaporated carbon. Secondary Electron and Backscattering images were obtained using a JEOL-JSM840A scanning electron microscope from the Physics Department of the Federal University of Minas Gerais, Belo Horizonte. Qualitative chemical analyses by SEM in the EDS mode were produced to support the mineral characterization and determine the elements to be analyzed by Electron probe microanalysis.

\subsection{Electron probe microanalysis (EPMA)}

EPMA was carried in a selection of two single crystals, with the performance of five spots per crystal. The chemical analysis was carried out with a Jeol JXA8900R spectrometer from the Physics Department of the Federal University of Minas Gerais, Belo Horizonte. For each selected element was used the following standards: Fe and Mg - olivine, Mn - rhodonite, P and Ca - Apatite Artimex, $\mathrm{Na}$ - Albite, $\mathrm{Al}$ - Corundum and $\mathrm{F}$ - Fluorite. The epoxy embedded matioliite samples were coated with a thin layer of evaporated carbon. The electron probe microanalysis in the WDS (wavelength dispersive spectrometer) mode was obtained at $15 \mathrm{kV}$ accelerating voltage and beam current of $10 \mathrm{nA}$.

\subsection{Raman microprobe spectroscopy}

Crystals of matioliite were placed on a polished metal surface on the stage of an Olympus BHSM microscope, which is equipped with $10 \times, 20 \times$, and $50 \times$ objectives. The microscope is part of a Renishaw 1000 Raman microscope system, which also includes a monochromator, a filter system and a CCD detector (1024 pixels). The Raman spectra were excited by a Spectra-Physics model 127 He-Ne laser producing highly polarized light at $633 \mathrm{~nm}$ and collected at a nominal resolution of $2 \mathrm{~cm}^{-1}$ and a precision of $\pm 1 \mathrm{~cm}^{-1}$ in the range between 200 and $4000 \mathrm{~cm}^{-1}$. Repeated acquisitions on the crystals using the highest magnification $(50 \times)$ were accumulated to improve the signal to noise ratio of the spectra. The spectra were collected over night. Raman Spectra were calibrated using the $520.5 \mathrm{~cm}^{-1}$ line of a silicon wafer. The Raman spectrum of at least 10 crystals was collected to ensure the consistency of the spectra.

\subsection{Infrared spectroscopy}

Infrared spectra were obtained using a Nicolet Nexus 870 FTIR spectrometer with a smart endurance single bounce diamond ATR cell. Spectra over the $4000-525 \mathrm{~cm}^{-1}$ range were obtained by the co-addition of 128 scans with a resolution of $4 \mathrm{~cm}^{-1}$ and a mirror velocity of $0.6329 \mathrm{~cm} / \mathrm{s}$. Spectra were co-added to improve the signal to noise ratio. The infrared spectra are given in the supplementary information. 
Spectral manipulation such as baseline correction/adjustment and smoothing were performed using the Spectracalc software package GRAMS (Galactic Industries Corporation, NH, USA). Band component analysis was undertaken using the Jandel 'Peakfit' software package that enabled the type of fitting function to be selected and allows specific parameters to be fixed or varied accordingly. Band fitting was done using a Lorentzian-Gaussian cross-product function with the minimum number of component bands used for the fitting process. The Gaussian-Lorentzian ratio was maintained at values greater than 0.7 and fitting was undertaken until reproducible results were obtained with squared correlations of $r^{2}$ greater than 0.995 .

\section{Results and discussion}

\subsection{Chemical characterization}

The SEM images of a matioliite crystals studied in this work are shown in Fig. 2. The image presented in the Fig. 2a was obtained with secondary electrons and shows a brazilianite crystal up to $3.0 \mathrm{~mm}$ in length, with matiollite growing on the surface. The matioliite crystals are organized in radiating groups of simple prismatic monoclinic crystals of about $0.2 \mathrm{~mm}$ in length. The mineral association suggests that matioliite grows after the crystallization of brazilianite. Fig. 2b was obtained with backscattered electrons and shows a single crystal of matioliite, with monoclinic prismatic to tabular form with up to $0.3 \mathrm{~mm}$ in length in the crystallographic $c$ axis.

The quantitative chemical analysis of matioliite is presented in Table 1 . The chemical composition indicates an intermediate member of the burangaite-matioliite series with predominance of the matioliite end-member. The results show variable amounts of $\mathrm{Fe}$ and $\mathrm{Ca}$, which replaces partially $\mathrm{Mg}$ and $\mathrm{Na}$, respectively.

\subsection{Spectroscopy}

The Raman spectrum of matioliite in the $100-4000 \mathrm{~cm}^{-1}$ region is displayed in Fig. 3a. This figure reports the position of the bands and their relative intensity. It is noted that there are regions in the spectrum where no intensity is observed. Therefore, the spectrum is subdivided into sections in subsequent figures so that more detailed assessment of the spectra can be made. In a similar way, the infrared spectrum of matioliite in the $500-4000 \mathrm{~cm}^{-1}$ region is reported in Fig. 1b. The spectrum is not shown below $500 \mathrm{~cm}^{-1}$. The reason is that we are using a reflectance technique
Table 1

Chemical composition of matioliite from Gentil pegmatite (mean of 10 electron microprobe analyses). $\mathrm{H}_{2} \mathrm{O}$ calculated by difference.

\begin{tabular}{lcll}
\hline Constituent & wt.\% & Range & Probe standard \\
\hline $\mathrm{MgO}$ & 4.68 & $3.61-5.57$ & Olivine \\
$\mathrm{FeO}$ & 2.20 & $1.02-3.85$ & Olivine \\
$\mathrm{MnO}$ & 0.06 & $0.03-0.15$ & Rhodonite \\
$\mathrm{CaO}$ & 0.05 & $0.00-0.21$ & Apatite Artimex \\
$\mathrm{Na}_{2} \mathrm{O}$ & 1.28 & $0.92-1.65$ & Albite \\
$\mathrm{Al}_{2} \mathrm{O}_{3}$ & 39.82 & $38.39-40.83$ & Corundum \\
$\mathrm{P}_{2} \mathrm{O}_{5}$ & 42.7 & $41.72-43.78$ & Apatite Artimex \\
$\mathrm{F}$ & 0.02 & $0.01-0.23$ & Fluorite \\
$\mathrm{H}_{2} \mathrm{O}$ & 9.19 & Calculated by difference \\
Total & 100.00 & & \\
\hline
\end{tabular}

is being used and the ATR cell absorbs all incident radiation below $500 \mathrm{~cm}^{-1}$. In a similar fashion to the Raman spectrum, the infrared spectrum is divided into sections depending upon the types of vibrations being observed. The Raman spectrum of matioliite in the $800-1400 \mathrm{~cm}^{-1}$ region is reported in Fig. 4a. The infrared spectrum of matioliite in the $500-1300 \mathrm{~cm}^{-1}$ region is reported in Fig. 4b.

The Raman spectrum in the $800-1400 \mathrm{~cm}^{-1}$ region is dominated by two very sharp bands of almost equal intensity at 1025 and $1048 \mathrm{~cm}^{-1}$. These two bands are assigned to the $v_{1} \mathrm{PO}_{4}^{3-}$ symmetric stretching mode. The observation of two symmetric stretching modes supports the concept that there are two non-equivalent phosphate units in the structure of matioliite. The higher wavenumber bands at 1068, 1104 are assigned to the $v_{3} \mathrm{PO}_{4}^{3-}$ antisymmetric stretching mode. The Raman band at $985 \mathrm{~cm}^{-1}$ is considered to be due to $\mathrm{HPO}_{4}^{2-}$ units.

Galy [17] first studied the polarized Raman spectra of the $\mathrm{H}_{2} \mathrm{PO}_{4}^{-}$ anion. Choi et al. [18] reported the polarization spectra of $\mathrm{NaH}_{2} \mathrm{PO}_{4}$ crystals. Casciani and Condrate [19] published spectra on brushite and monetite together with synthetic anhydrous monocalcium phosphate $\left[\mathrm{Ca}\left(\mathrm{H}_{2} \mathrm{PO}_{4}\right)_{2}\right]$, monocalcium dihydrogen phosphate hydrate $\left(\mathrm{Ca}\left(\mathrm{H}_{2} \mathrm{PO}_{4}\right)_{2} \cdot \mathrm{H}_{2} \mathrm{O}\right)$ and octacalcium phosphate $\left[\mathrm{Ca}_{8} \mathrm{H}_{2}\left(\mathrm{PO}_{4}\right)_{6} \cdot 5 \mathrm{H}_{2} \mathrm{O}\right]$. These authors determined band assignments for $\mathrm{Ca}\left(\mathrm{H}_{2} \mathrm{PO}_{4}\right)$ and reported bands at 1002 and $1011 \mathrm{~cm}^{-1}$ as $\mathrm{POH}$ and $\mathrm{PO}$ stretching vibrations, respectively. The two Raman bands at 1139 and $1165 \mathrm{~cm}^{-1}$ are attributed to both the HOP and PO antisymmetric stretching vibrations. Casciani and Condrate [19] tabulated Raman bands at 1132 and $1155 \mathrm{~cm}^{-1}$ and assigned these bands to $\mathrm{P}-\mathrm{O}$ symmetric and the $\mathrm{P}-\mathrm{O}$ antisymmetric stretching vibrations. Raman spectroscopy identifies the presence of phosphate,
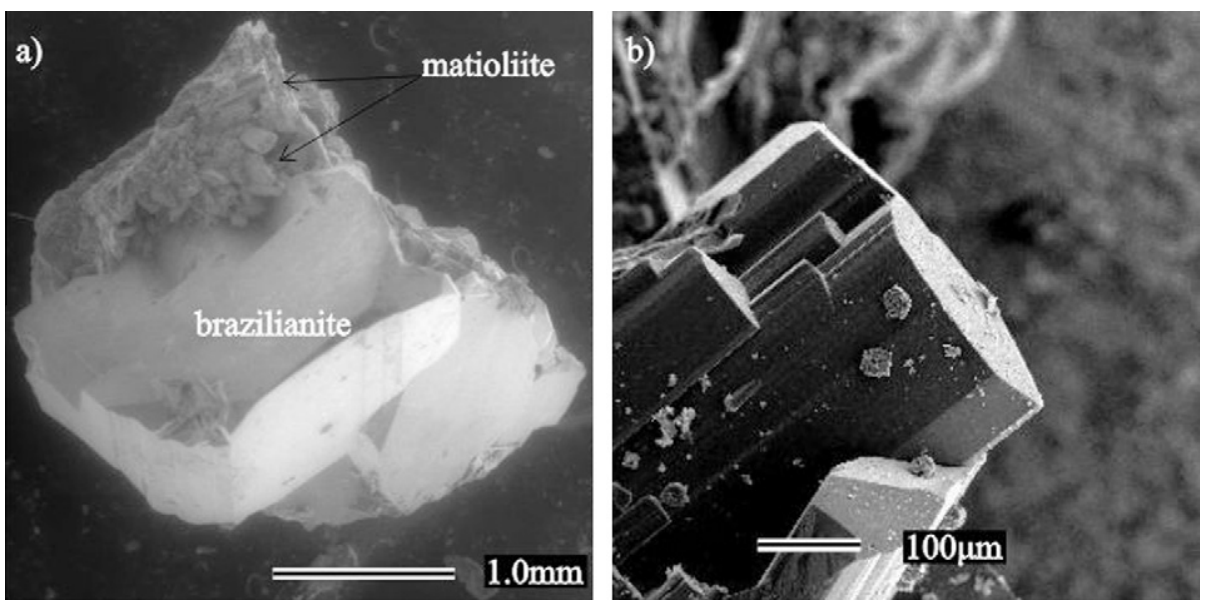

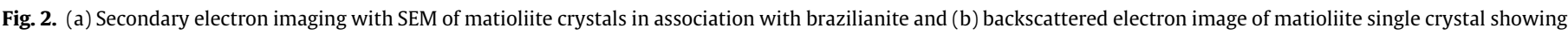
monoclinic prismatic form. Crystal up to $500 \mu \mathrm{m}$. 

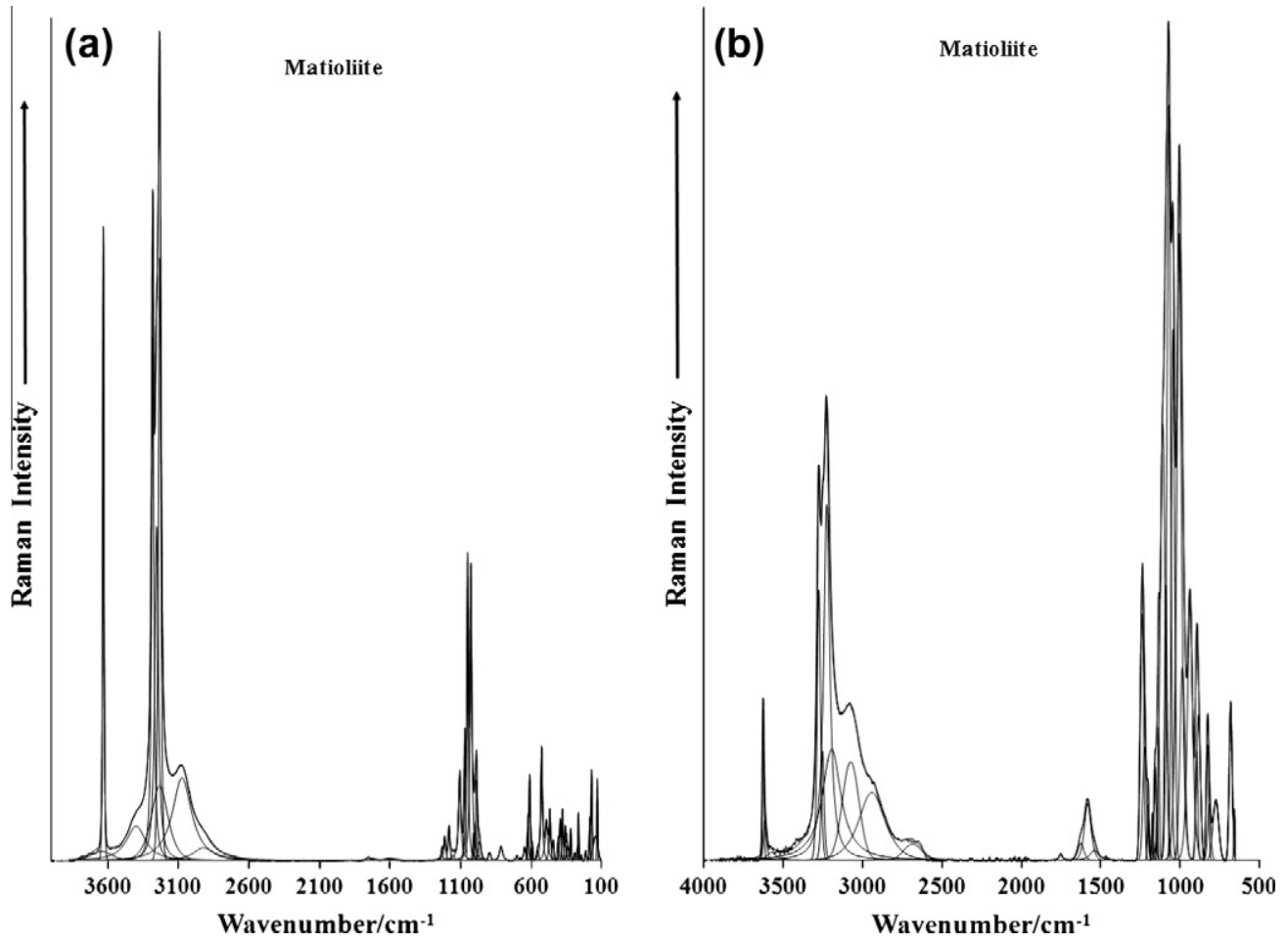

Fig. 3. (a) Raman Spectrum of matioliite the $100-4000 \mathrm{~cm}^{-1}$ region and (b) infrared spectrum of matioliite in the $500-4000 \mathrm{~cm}^{-1}$ region.
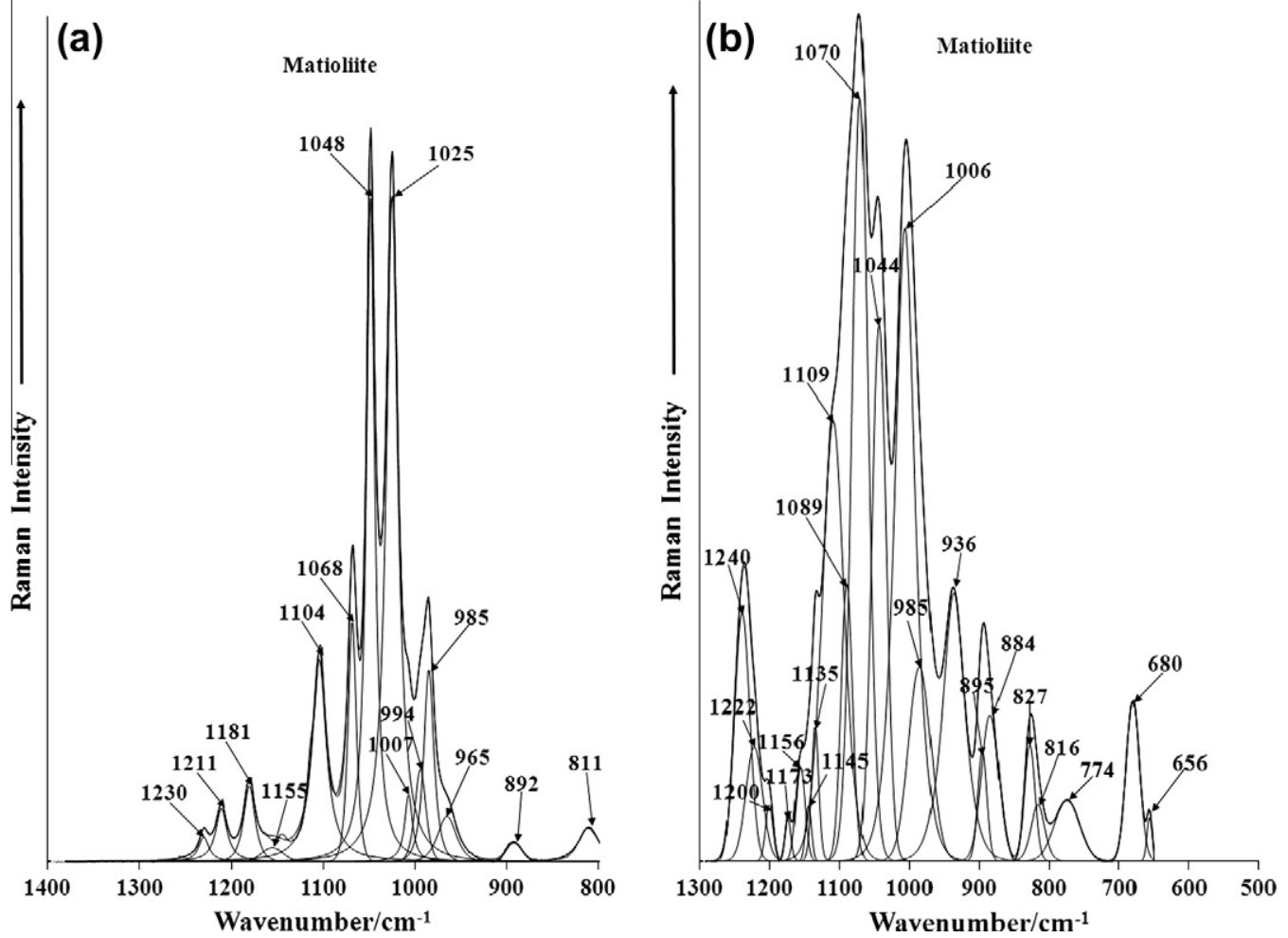

Fig. 4. (a) Raman spectrum of matioliite in the $800-1400 \mathrm{~cm}^{-1}$ region and (b) infrared spectrum of matioliite in the $500-1300 \mathrm{~cm}^{-1}$.

hydrogen phosphate and dihydrogen phosphate units. The infrared spectrum (Fig. $4 \mathrm{~b}$ ) show a complex set of overlapping bands. The two infrared bands at 985 and $1006 \mathrm{~cm}^{-1}$ are attributed to the $v_{1}$ $\mathrm{PO}_{4}^{3-}$ symmetric stretching modes. The intense bands at 1044 , 1070,1109 and $1135 \mathrm{~cm}^{-1}$ are assigned to the $v_{3} \mathrm{PO}_{4}^{3-}$ antisymmetric stretching modes.
The Raman spectra of matioliite in the $300-800 \mathrm{~cm}^{-1}$ and in the $100-300 \mathrm{~cm}^{-1}$ region are shown in Fig. $5 \mathrm{a}$ and $\mathrm{b}$ respectively. The spectra show the complexity in harmony with the spectrum reported in Fig. 4a and b. The Raman spectral region shown in Fig. 6a represents the bending region of the phosphate units. A set of Raman bands at 590, 599, 609 and $620 \mathrm{~cm}^{-1}$ are assigned 

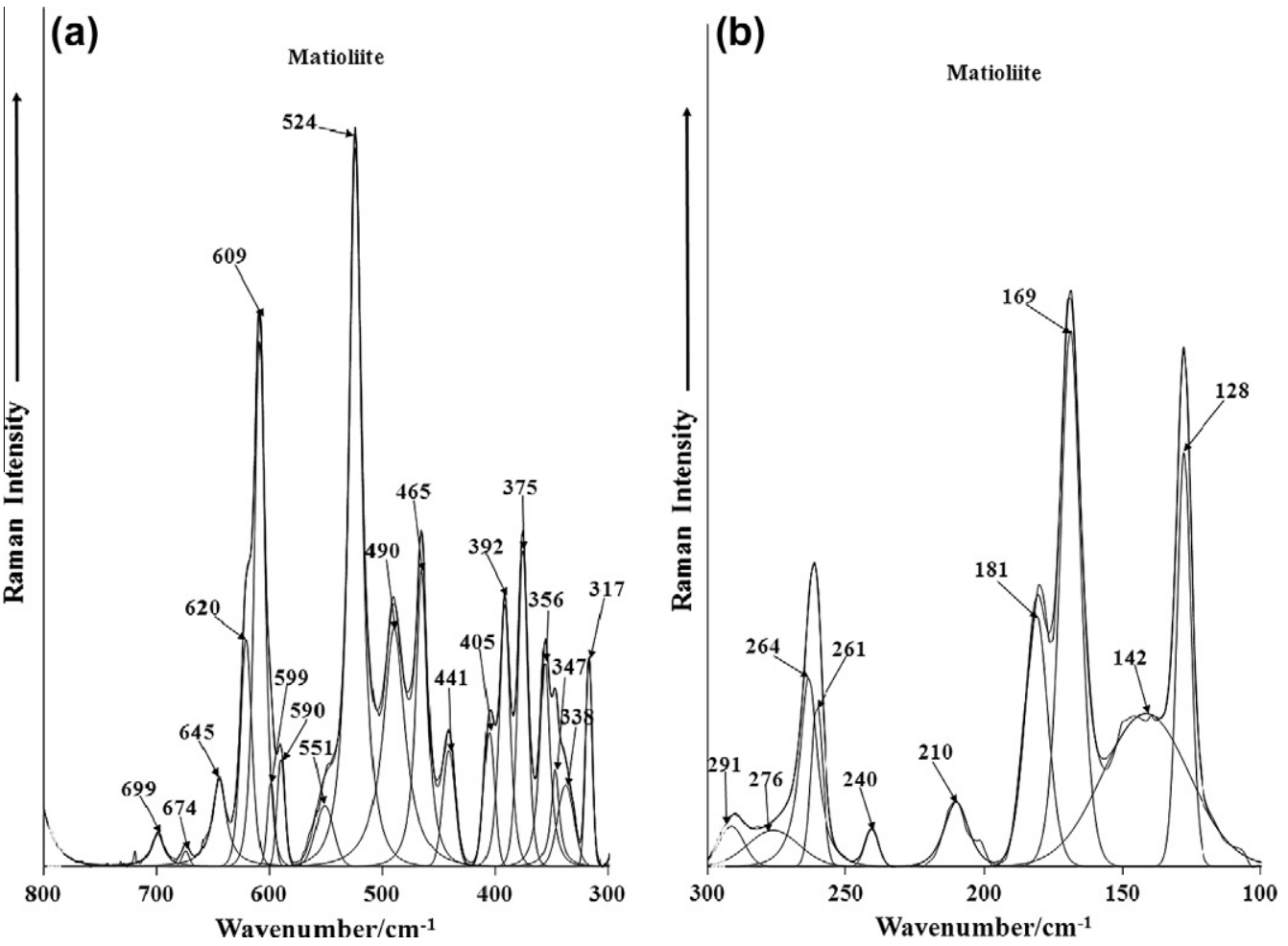

Fig. 5. (a) Raman spectra of matoiliite in the $300-800 \mathrm{~cm}^{-1}$ and (b) Raman spectra of matoiliite in the $100-300 \mathrm{~cm}^{-1}$ region.
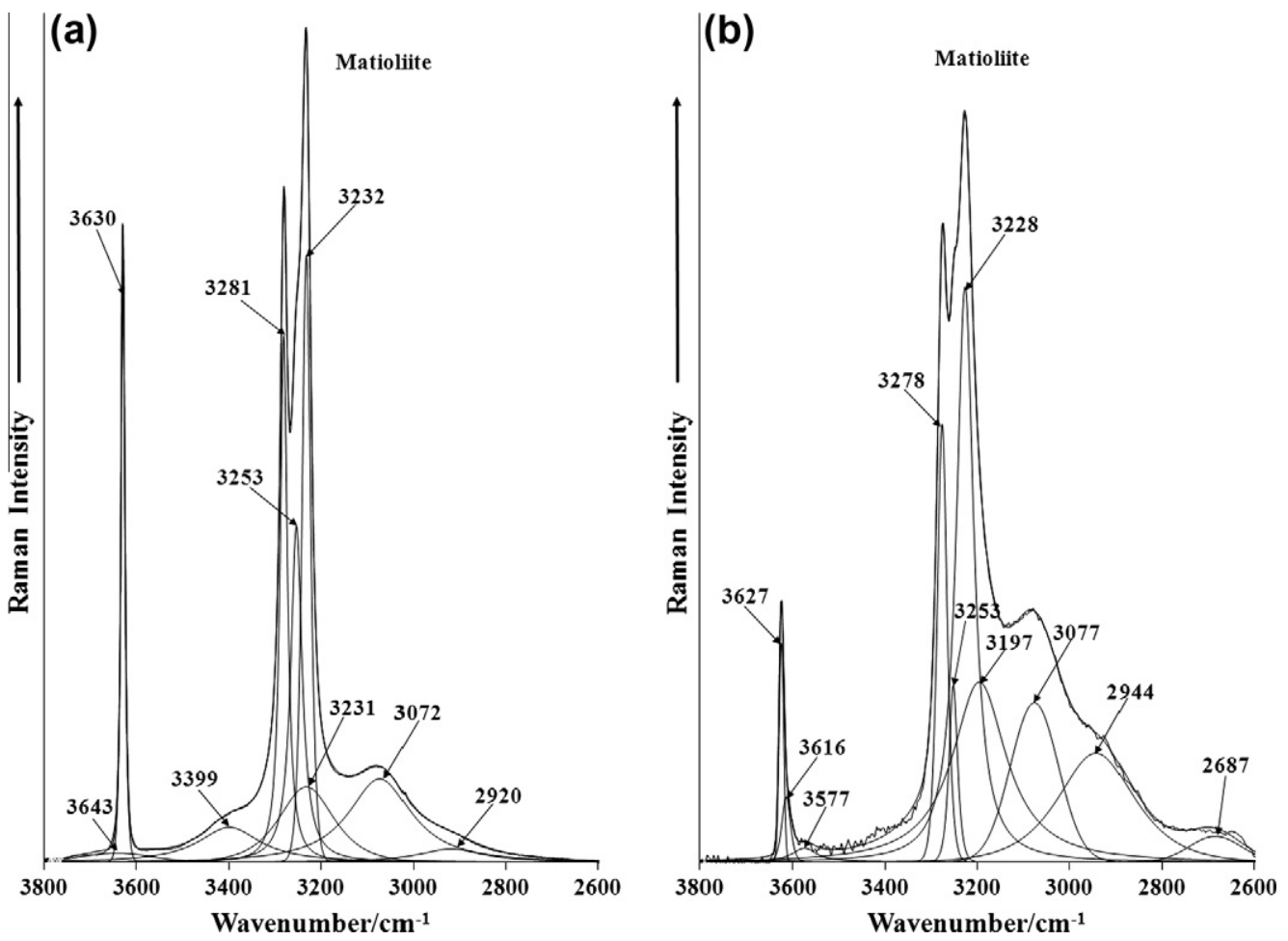

Fig. 6. (a) Raman spectrum of matioliite in the $2600-3800 \mathrm{~cm}^{-1}$ region and (b) infrared spectrum of matioliite in the $2600-3800 \mathrm{~cm}^{-1} \mathrm{region}_{\text {. }}$

to the $v_{4}$ out of plane bending modes of the $\mathrm{PO}_{4}, \mathrm{HPO}_{4}$ and $\mathrm{H}_{2} \mathrm{PO}_{4}$ units. The Raman spectrum of $\mathrm{NaH}_{2} \mathrm{PO}_{4}$ shows Raman bands at 526, 546 and $618 \mathrm{~cm}^{-1}$ (this work). The infrared spectrum of matoiliite (Fig. 4b) shows two bands at 656 and $680 \mathrm{~cm}^{-1}$ and is assigned to this vibrational mode. In the infrared spectrum of dittmarite $\left(\left(\mathrm{NH}_{4}\right) \mathrm{MgPO}_{4} \cdot \mathrm{H}_{2} \mathrm{O}\right)$ bands are observed at 635 and
$656 \mathrm{~cm}^{-1}$ and are assigned to the $\mathrm{PO}_{4}^{3-} v_{4}$ bending mode. Raman bands are observed at 441,465, 490 and $524 \mathrm{~cm}^{-1}$. These bands are attributed to the $v_{2} \mathrm{PO}_{4}, \mathrm{HPO}_{4}$ and $\mathrm{H}_{2} \mathrm{PO}_{4}$ bending modes. The Raman spectrum of $\mathrm{NaH}_{2} \mathrm{PO}_{4}$ shows Raman bands at 460 and $482 \mathrm{~cm}^{-1}$ which are assigned to this vibrational mode. A set of Raman bands is observed at 317, 338, 347, 356, 375, 392 and 

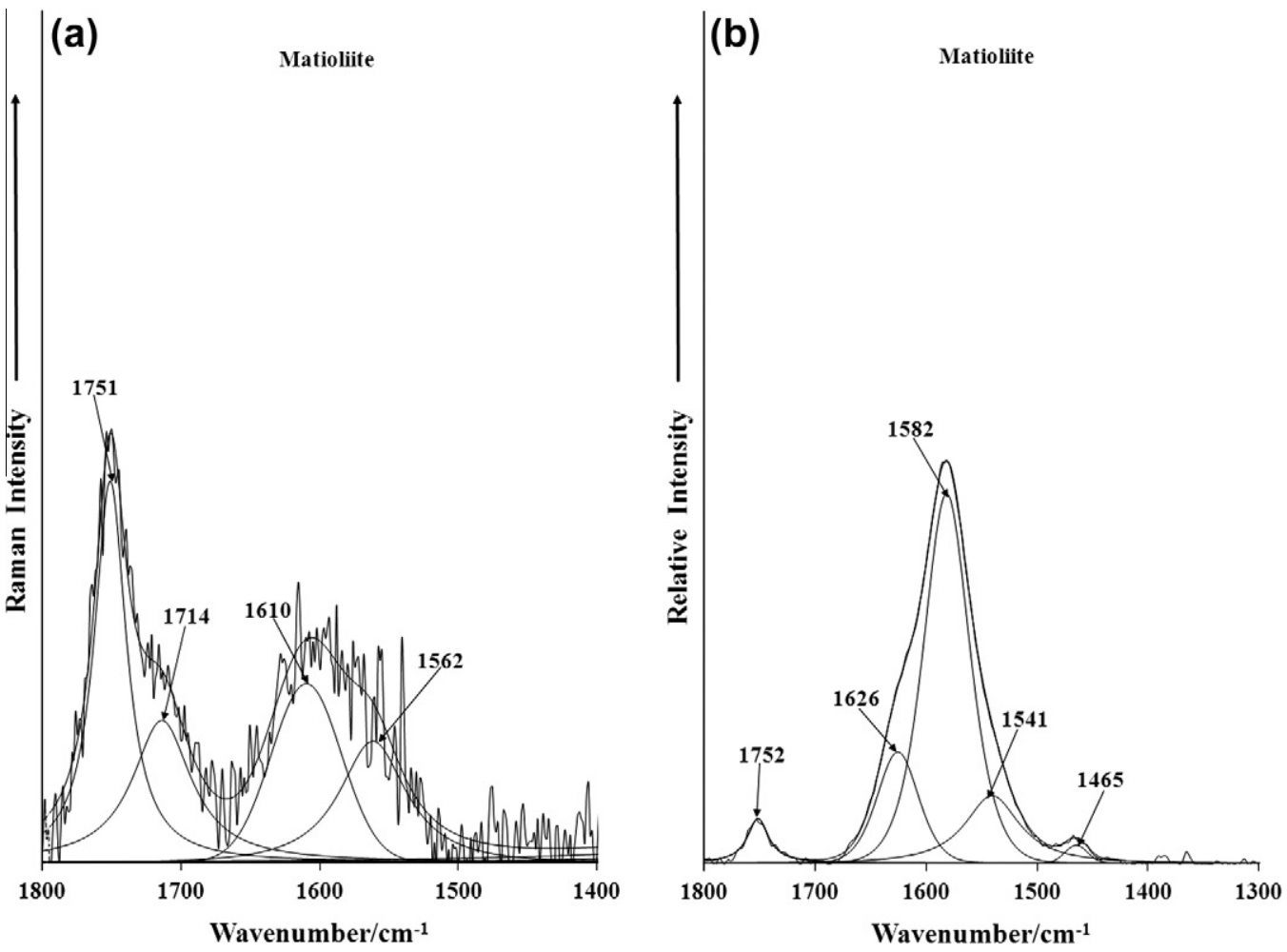

Fig. 7. (a) Raman spectrum of matioliite in the $1400-1800 \mathrm{~cm}^{-1}$ region and (b) infrared spectrum of matioliite in the $1300-1800 \mathrm{~cm}^{-1}$ region.

$405 \mathrm{~cm}^{-1}$. These bands are considered to be due to metal-oxygen stretching vibrations. Strong Raman bands are observed in the far low wavenumber region at 128, 169, 181, 261 and $264 \mathrm{~cm}^{-1}$. These bands are described as lattice vibrations.

The Raman spectrum of matioliite and the infrared spectrum in the $2600-3800 \mathrm{~cm}^{-1}$ region are illustrated in Fig. $6 \mathrm{a}$ and b. Raman peaks are observed at 3232,3281 and $3630 \mathrm{~cm}^{-1}$; the first two peaks are assigned to water stretching vibrations and the latter to $\mathrm{OH}$ stretching bands. Other low intensity Raman bands are observed at 2920, 3072, 3231 and $3399 \mathrm{~cm}^{-1}$. These bands show much greater intensity in the infrared spectrum. Two intense infrared bands are observed at 3228 and $3278 \mathrm{~cm}^{-1}$ and are assigned to water stretching vibrations. The infrared band at $3627 \mathrm{~cm}^{-1}$ is attributed to $\mathrm{OH}$ unit stretching vibration. Other infrared bands are observed at 2678, 2944, 3077, 3197 and $3525 \mathrm{~cm}^{-1}$. The observation of two distinct Raman stretching vibrations for matioliite suggests that there are two distinct non-equivalent water molecules in the structure. This concept is supported by the multiple infrared bands. In comparison, only a single $\mathrm{OH}$ stretching vibration is observed in both the infrared and Raman spectrum, thus indicating that all the $\mathrm{OH}$ units are spectroscopically identical.

The Raman spectrum in the $1400-1800 \mathrm{~cm}^{-1}$ and the infrared spectrum in the $1300-1800 \mathrm{~cm}^{-1}$ are reported in Fig. 7a and b respectively. A low intensity Raman band is observed at $1610 \mathrm{~cm}^{-1}$ and is attributed to the water bending mode. The band shows much greater intensity in the infrared spectrum and is observed as a band at $1626 \mathrm{~cm}^{-1}$. The Raman spectrum shows a band at $1751 \mathrm{~cm}^{-1}$ with a shoulder band at $1714 \mathrm{~cm}^{-1}$. These bands are also reflected in the infrared spectrum with the band observed at $1752 \mathrm{~cm}^{-1}$. These bands are attributed to overtone or combination bands. In the infrared spectrum bands are observed at 1465, 1541 and $1582 \mathrm{~cm}^{-1}$.

\section{Conclusions}

Matioliite is a rare hydrated basic aluminum phosphate mineral with sodium and magnesium and forms a solid solution with burangaite where magnesium is substituted by iron. A sample of matioliite from the type locality was characterized by EPMA SEM and Raman and infrared spectroscopic measurements. Chemical composition shows an intermediate member in the solid solution with predominance of the matioliite end-member.

\section{Acknowledgements}

The financial and infra-structure support of the Discipline of Nanotechnology and Molecular Science, Science and Engineering Faculty of the Queensland University of Technology, is gratefully acknowledged. The Australian Research Council (ARC) is thanked for funding the instrumentation. R. Scholz thanks to FAPEMIG Fundação de Amparo à Pesquisa do Estado de Minas Gerais (Grant No. CRA-APQ-03998-10).

\section{References}

[1] O. von Knorring, M. Lehtinen, Th.G. Sahama, Bull. Geol. Soc. Finland 49 (1977) 33.

[2] D. Atencio, J.M.V. Coutinho, Y.P. Mascarenhas, J.A. Ellena, Am. Mineral. 91 (2006) 1932

[3] M. Jensen, J.C. Rota, E.E. Foord, Mineral. Rec. 26 (1995) 449

[4] F. Walter, K. Ettinger, Carinthia II (191) (2001) 149.

[5] M.L.S.C. Chaves, R. Scholz, D. Atencio, J. Karfunkel, Geociências 24 (2005) 143 (in Portuguese)

[6] M.L.S.C. Chaves, R. Scholz, Revista Escola de Minas 61 (2008) 141

[7] J.B. Selway, M.A. Cooper, F.C. Hawthorne, Can. Mineral. 35 (1997) 1515.

[8] R.L. Frost, M.L. Weier, K.L. Erickson, L. Kristy, O. Carmody, S. Mills, J. Raman Spectrosc. 35 (2004) 1047

[9] L.N. Dias, M.V.B. Pinheiro, R.L. Moreira, K. Krambrock, K. Guedes, L.A.D. Menezes Filho, J. Karfunkel, J. Schnellrath, R. Scholz, Am. Mineral. 96 (2011) 42. 
[10] R.L. Frost, Y. Xi, S.J. Palmer, R. Pogson, Spectrochim. Acta A: Mol. Biomol. Spectrosc. 82 (2011) 461.

[11] R.L. Frost, Y. Xi, S.J. Palmer, J. Mol. Struct. 1001 (2011) 56.

[12] R.L. Frost, Y. Xi, J. Mol. Struct. 1010 (2012) 179.

[13] V.C. Farmer, Mineralogical Society Monograph 4, The Infrared Spectra of Minerals, 1974.

[14] R.L. Frost, W. Martens, P.A. Williams, J.T. Kloprogge, Mineral. Mag. 66 (2002) 1063.
[15] R.L. Frost, W.N. Martens, T. Kloprogge, P.A. Williams, Neues Jahrbuch für Mineralogie, Monatschefte 11 (2002) 481.

[16] R.L. Frost, P.A. Williams, W. Martens, J.T. Kloprogge, P. Leverett, J. Raman Spectrosc. 33 (2002) 260.

[17] A. Galy, J. Phys - Paris 12 (1951) 827.

[18] B.K. Choi, M.N. Lee, J.J. Kim, J. Raman Spectrosc. 20 (1989) 11.

[19] F.S. Casciani, R.A. Condrate Sr., Proceedings - International Congress on Phosphorus Compounds, 2nd, 1980, pp. 175. 